\title{
SISTEM REKOMENDASI UNTUK MENENTUKAN LEVEL KOMPETENSI PENGAJAR DENGAN METODE MULTIPLE ATTRIBUTE DECISION MAKING: STUDI KASUS DI NURUL FIKRI COMPUTER
}

\author{
Nasrul 1), Dana Indra Sensuse 2) \\ Program Pascasarjana, Universitas Budi Luhur \\ Email: nasrul99@gmail.com
}

\begin{abstract}
ABSTRAK
Nurul Fikri Computer yang juga dikenal dengan NF COMPUTER merupakan sebuah lembaga komputer yang melayani jasa training komputer untuk lembaga pemerintah, swasta, dan masyarakat umum. Seiring dengan banyaknya permintaan pelatihan komputer, maka pemetaan level kompetensi pengajar menjadi suatu keharusan. Kendala yang dihadapi manajemen NF COMPUTER saat ini adalah merasakan kesulitan terhadap proses penentuan level kompetensi pengajar, karena banyak begitu banyak faktor untuk menentukan level kompetensi pengajar. Tujuan penelitian ini adalah menentukan kinerja sistem informasi untuk menentukan level kompetensi pengajar secara tepat dengan pendekatan metode Multiple Attribute Decision Making (MADM) yang merupakan sebuah metode untuk menentukan sebuah keputusan dengan banyaknya kriteria. Penelitian ini membandingankan beberapa metode yang termasuk metode MADM dan selanjutnya dibandingkan dengan pendapat para pakar. Hasil perbandingannya adalah $80 \%$ sama pada lima peringkat teratas dan $100 \%$ sama pada lima peringkat terbawah. Setelah aplikasi selesai dibuat, penulis melakukan pengujian sistem tersebut dengan mengunakan metode User Acceptance Test (UAT) dengan hasil $81 \%$. Hasil pengujian ini dapat dikatakan baik dan bisa diaplikasikan ke dalam sebuah sistem informasi untuk menentukan level kompetensi pengajar dengan tepat.
\end{abstract}

Kata kunci: Sistem Informasi, Pemetaan, Level, Kompetensi, Pengajar, Multiple Attribute Decision Making

\section{Pendahuluan}

Nurul Fikri Computer yang disingkat NF COMPUTER merupakan sebuah lembaga yang memadukan antara pelatihan dan pendidikan di bidang Teknologi Informasi dan Komunikasi. Seiring dengan banyaknya permintaan pelatihan komputer kepada NF COMPUTER, maka pemetaan kompetensi pengajar menjadi suatu keharusan. Kendala yang dihadapi manajemen NF COMPUTER saat ini adalah merasakan kesulitan terhadap proses penentuan level kompetensi pengajar, karena banyak begitu banyaknya faktor untuk menentukan level kompetensi pengajar.

Dengan begitu banyak faktor untuk menentukan level kompetensi pengajar, dipilihlah metode Multiple Attribute Decision Making (MADM) yang merupakan sebuah metode untuk menentukan sebuah keputusan dengan banyaknya kriteria untuk menentukan level pengajar di NF COMPUTER.

\section{Landasan Teori $2.1 \quad$ Kompetensi}

Kompetensi adalah kekuasaan untuk menentukan atau memutuskan suatu hal [1]. kompetensi adalah perpaduan dari penguasaan, pengetahuan, keterampilan, nilai dan sikap yang direfleksikan dalam kebiasaan berpikir dan bertindak dalam melaksanakan tugas atau pekerjaannya [2]. Kompetensi merupakan karakteristik yang menonjol bagi seseorang dan menjadi cara-cara berperilaku dan berfikir dalam segala situasi, dan berlangsung dalam periode waktu yang lama [3].

Dari pendapat di atas ada lima karakteristik kompetensi yaitu sebagai berikut [4]:

1. Motif, yaitu sesuatu yang orang pikirkan dan inginkan yang menyebabkan sesuatu.

2. Sifat, yaitu karakteritik fisik tanggapan konsisten terhadap situasi.

3. Konsep diri, yaitu sikap, nilai, dan image dari sesorang. 
4. Pengetahuan, yaitu informasi yang dimiliki seseorang dalam bidang tertentu.

5. Keterampilan, yaitu kemampuan untuk melakukan tugas-tugas yang berkaitan dengan fisik dan mental.

Kompetensi merupakan perpaduan dari pengetahuan, ketrampilan, nilai dan sikap yang direfleksikan dalam kebiasaan berpikir dan bertindak. Pada sistem pengajaran, kompetensi digunakan untuk mendeskripsikan kemampuan profesional yaitu kemampuan untuk menunjukkan pengetahuan dan konseptualisasi pada tingkat yang lebih tinggi. Kompetensi ini dapat diperoleh melalui pendidikan, pelatihan dan pengalaman lain sesuai tingkat kompetensinya [5].

Menurut Undang-Undang No. 14 Tahun 2005 tentang Pengajar dan Dosen, kompetensi adalah seperangkat pengetahuan, ketrampilan, dan perilaku yang harus dimiliki, dihayati dan dikuasai oleh pengajar atau dosen dalam melaksanakan tugas keprofesionalan.

Pengajar memiliki pengaruh luas dalam dunia pendidikan. Di lembaga pendidikan dia adalah pelaksana pendidikan yaitu bertanggung jawab agar pendidikan dapat berlangsung dengan baik. Pengajar wajib memiliki kualifikasi akademik, kompetensi, sertifikat pendidik, sehat jasmani dan rohani, serta memiliki kemampuan untuk mewujudkan tujuan pendidikan nasional [6].

Kompetensi merupakan perpaduan dari penguasaan, pengetahuan, keterampilan, nilai dan sikap yang direfleksikan dalam kebiasaan berpikir dan bertindak dalam melaksanakan tugas atau pekerjaannya [2].

Kompetensi adalah kecakapan, kemampuan dan keterampilan yang dimiliki oleh seseorang yang bertugas mendidik siswa agar mempunyai kepribadian yang luhur dan mulia sebagaimana tujuan dari pendidikan [7].

Dari beberapa pengertian yang sudah disebutkan di atas dapat disimpulkan bahwa kompetensi merupakan seperangkat penguasaan kemampuan, ketrampilan, nilai, dan sikap yang harus dimiliki, dihayati, dan dikuasai pengajar yang bersumber dari pendidikan, pelatihan, dan pengalamannya sehingga dapat menjalankan tugas mengajarnya secara profesional.

\subsection{Multiple Attribute Decision Making}

Multiple Attribute Decision Making (MADM) adalah salah satu model dari Multiple Criteria Decision Making (MCDM) yang merupakan metode pengambilan keputusan untuk menetapkan alternatif terbaik dari sejumlah alternatif berdasarkan beberapa kriteria yang telah ditentukan.
MADM digunakan untuk melakukan penelitian atau seleksi terhadap beberapa alternatif dalam jumlah terbatas. Pada dasarnya, ada tiga pendekatan untuk mencari nilai bobot atribut, yaitu pendekatan subyektif, pendekatan obyektif dan pendekatan integrasi antara subyektif dan obyektif. Masingmasing pendekatan memiliki kelebihan dan kelemahan. Pada pendekatan subyektif, nilai bobot ditentukan berdasarkan subyektifitas dari para pengambil keputusan, sehingga beberapa faktor dalam proses perankingan alternatif bisa ditentukan secara bebas. Sedangkan pada pendekatan obyektif, nilai bobot dihitung secara matematis sehingga mengabaikan subyektifitas dari pengambil keputusan [8]

Ada beberapa metode lain yang dapat digunakan untuk menyelesaikan masalah FMADM (Fuzzy Multiple Attribut Decision Making), antara lain (Hasugian, 2017):

1. WP (Weighted Product)

2. TOPSIS (Tecnique for Order Preference by Similarity to Ideal Solution)

3. AHP (Analytic Hierarchy Process)

4. ELECTRE

5. SAW (Simple Additive Weighting)

\section{Metodologi dan Rancangan Penelitian 3.1 Metodologi Penelitian}

Penelitian ini menggunakan metode deskriptif kualitatif. Penelitian deskriptif kualitatif merupakan penelitian yang termasuk dalam jenis penelitian kualitatif. Penelitian ini adalah mengungkap fakta, keadaan, fenomena, variabel dan keadaan yang terjadi saat penelitian berjalan dan menyuguhkan apa adanya. Penelitian deskriptif kualitatif menafsirkan dan menuturkan data yang bersangkutan dengan situasi yang sedang terjadi, sikap serta pandangan yang terjadi, pertentangan dua keadaan atau lebih, hubungan antar variabel, perbedaan antar fakta, pengaruh terhadap suatu kondisi, dan lain-lain. Kegiatan penelitian ini meliputi pengumpulan data, menganalisis data, menginterprestasi data, dan diakhiri dengan sebuah kesimpulan yang mengacu pada penganalisisan data tersebut.

Metode deskriptif kualitatif ini dipilih karena untuk kasus analisis kebutuhan pengembangan perangkat lunak metode ini lebih relevan. Relevan dalam artian untuk proses analisa kebutuhan penelitian ini dilakukan proses wawancara dan hasil dari wawancara ini berupa data bersifat deskriptif. Metodologi kualitatif sebagai prosedur penelitian yang menghasilkan data deskriptif berupa kata-kata tertulis atau lisan dari orang-orang dan perilaku yang dapat diamati [10]. 


\subsection{Rancangan Penelitian}

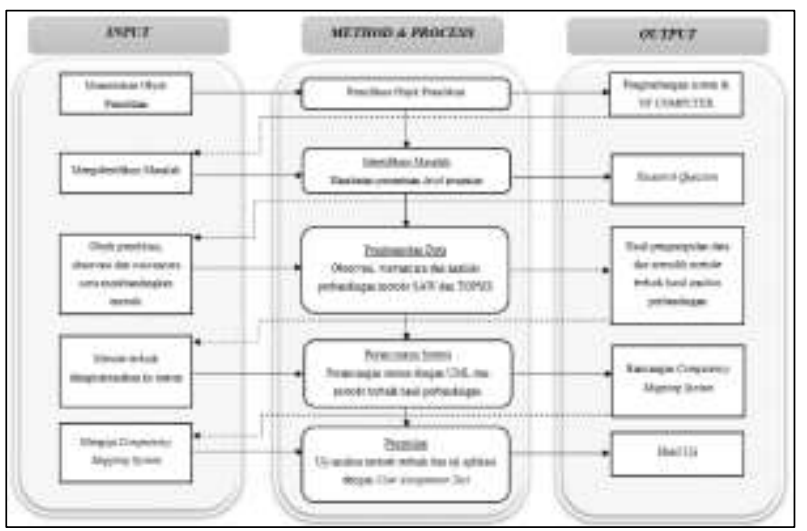

Gambar 3.1: Tahapan Penelitian

Gambar 3.1 adalah rancangan penelitian yang dijadikan dasar sebagai langkah-langkah peneliti dalam melakukan penelitian:

1. Pemilihan Objek Penelitian

Langkah awal penelitian ini adalah menentukan objek penelitian, yaitu di NF COMPUTER dengan mengambil kasus pada penentuan level kompetensi pengajar.

2. Identifikasi Masalah

Pada tahap ini dilakukan identifikasi masalah yang ada pada unit terkait. Output dari langkah ini adalah research question atau rumusan masalah.

3. Pengumpulan Data

Research question atau rumusan masalah kemudian menjadi input pada tahap ini. Proses yang dilakukan selanjutnya adalah pengumpulan data berupa observasi, wawancara, pengumpulan dokumen terkait dan studi literatur yang berkaitan dengan rumusan masalah. Output pada tahap ini adalah hasil pengumpulan data berupa bisnis proses yang sedang berjalan dan user requirement untuk pengembangan sistem. Untuk mendapatkan hasil yang tepat, penulis membandingkan dua jenis metode yang termasuk jenis Multiple Attribute Decision Making (MADM) yaitu metode Simple Additive Weighting (SAW) dan Tecnique for Order Preference by Similarity to Ideal Solution (TOPSIS). Hasil terbaik dari analisis perbandingan kedua metode tersebut, kemudian diimplementasikan ke dalam pengembangan sistem.

4. Perancangan

Setelah mendapatkan metode terbaik dari hasil perbandingan metode, selanjutnya hasil pengumpulan data pada tahap sebelumnya menjadi input pada tahap ini. Kemudian dilakukan analisis Competency Mapping System untuk menentukan level pengajar dengan menggunakan metode terbaik hasil perbandingan yang telah dilakukan. Selanjutnya sistem informasi dirancang dengan pendekatan Unified Modeling Language (UML) yang merupakan sebuah bahasa spesifikasi standar untuk mendokumentasikan, menspesifikasikan dan membangun sistem perangkat lunak. Output dari tahap ini adalah rancangan Competency Mapping System.

5. Pengujian

a. Pengujian terhadap analisis perbandingan dua metode MDAM yaitu metode SAW dan TOPSIS. Hasil pengujian kedua metode tersebut kemudian dibandingkan lagi dengan pendapat para pakar. Hasil terbaik dari hasil perbandingan tersebut kemudian dikembangkan ke dalam sebuah sistem informasi.

b. Setelah sistem dikembangkan, proses selanjutnya adalah dilakukan pengujian terhadap fungsionalitas sistem menggunakan User Acceptance Test seperti pada lampiran.

\section{Pembahasan Hasil Penelitian 4.1 Analisis Uji SAW}

Analisis pengujian metode SAW diawali dengan mendapatkan data pengajar NF COMPUTER yang akan dinilai level kompetensinya. Dalam pengujian model sistem ini data pengajar disebut sebagai nilai alternatif. Berikut ini adalah data pengajar NF COMPUTER:

1. Laisa Nurin Mentari (A1)

2. Sugandi (A2)

3. Yuliadi (A3)

4. Nasrul (A4)

5. Hafidz At-Tamim (A5)

6. Henry Saptono (A6)

7. Daseh Hidayat (A7)

8. Achmad Ilham (A8)

9. Edo Riansyah (A9)

10. Sirojul Munir (A10)

Setelah mendapatkan data nilai alternatifnya, selanjutnya ditentukan kriteria-kriteria untuk menentukan level kompetensi pengajar dengan datadata sebagai berikut :

1. Pendidikan Formal (C1)

2. Pelatihan / Kursus (C2)

3. Kompetensi Teknis (C3)

4. Kompetensi Metodologi (C4)

5. Hasil Karya Modul Kursus (C5)

6. Sertifikasi Kompetensi Berskala Nasional (C6)

7. Sertifikat Kompetensi Berskala Internasional (C7)

8. Durasi Jam Mengajar dalam Setahun (C8)

9. Masa / Lama Kerja (C9) 
Tabel 4.1: Tabel Nilai Kriteria Alternatif Metode SAW

\begin{tabular}{|c|c|c|c|c|c|c|c|c|c|}
\hline \multirow{2}{*}{ A } & \multicolumn{7}{|c|}{ Kriteria } \\
\cline { 2 - 10 } & $\mathbf{C 1}$ & $\mathbf{C 2}$ & $\mathbf{C 3}$ & $\mathbf{C 4}$ & $\mathbf{C 5}$ & $\mathbf{C 6}$ & $\mathbf{C 7}$ & $\mathbf{C 8}$ & $\mathbf{C 9}$ \\
\hline A1 & 75 & 70 & 80 & 75 & 10 & 50 & 50 & 15 & 20 \\
\hline A2 & 75 & 100 & 80 & 100 & 30 & 50 & 50 & 45 & 100 \\
\hline A3 & 70 & 100 & 100 & 85 & 50 & 50 & 50 & 30 & 10 \\
\hline A4 & 85 & 100 & 100 & 100 & 100 & 90 & 50 & 100 & 100 \\
\hline A5 & 75 & 100 & 90 & 100 & 50 & 70 & 50 & 65 & 100 \\
\hline A6 & 85 & 100 & 100 & 100 & 100 & 100 & 70 & 100 & 100 \\
\hline A7 & 65 & 60 & 70 & 59 & 10 & 50 & 50 & 15 & 100 \\
\hline A8 & 75 & 100 & 80 & 75 & 20 & 50 & 50 & 30 & 90 \\
\hline A9 & 75 & 100 & 100 & 75 & 30 & 60 & 50 & 100 & 100 \\
\hline A10 & 85 & 100 & 100 & 100 & 100 & 100 & 70 & 100 & 100 \\
\hline
\end{tabular}

Data pada Tabel 4.1 merupakan nilai semua kriteria untuk menentukan level kompetensi pengajar dari semua alternatif yang ada. Untuk selanjutnya semua nilai kriteria yang ada, nilainya akan dinormalisasi.

Tabel 4.2: Nilai Normalisasi Metode SAW

\begin{tabular}{|c|c|c|c|c|c|c|c|c|c|}
\hline \multirow{2}{*}{$\mathbf{A}$} & \multicolumn{9}{|c|}{ Normalisasi } \\
\hline & C1 & C2 & C3 & C4 & C5 & C6 & C7 & C8 & C9 \\
\hline $\mathrm{A} 1$ & 0,88 & 0,70 & 0,80 & 0,75 & 0,10 & 0,50 & 0,71 & 0,15 & 0,20 \\
\hline $\mathrm{A} 2$ & 0,88 & 1,00 & 0,80 & 1,00 & 0,30 & 0,50 & 0,71 & 0,45 & 1,00 \\
\hline $\mathrm{A} 3$ & 0,82 & 1,00 & 1,00 & 0,85 & 0,50 & 0,50 & 0,71 & 0,30 & 0,10 \\
\hline $\mathrm{A} 4$ & 1,00 & 1,00 & 1,00 & 1,00 & 1,00 & 0,90 & 0,71 & 1,00 & 1,00 \\
\hline A5 & 0,88 & 1,00 & 0,90 & 1,00 & 0,50 & 0,70 & 0,71 & 0,65 & 1,00 \\
\hline A6 & 1,00 & 1,00 & 1,00 & 1,00 & 1,00 & 1,00 & 1,00 & 1,00 & 1,00 \\
\hline A7 & 0,76 & 0,60 & 0,70 & 0,59 & 0,10 & 0,50 & 0,71 & 0,15 & 1,00 \\
\hline A8 & 0,88 & 1,00 & 0,80 & 0,75 & 0,20 & 0,50 & 0,71 & 0,30 & 0,90 \\
\hline A9 & 0,88 & 1,00 & 1,00 & 0,75 & 0,30 & 0,60 & 0,71 & 1,00 & 1,00 \\
\hline A10 & 1,00 & 1,00 & 1,00 & 1,00 & 1,00 & 1,00 & 1,00 & 1,00 & 1,00 \\
\hline
\end{tabular}

Data pada Tabel 4.2 merupakan nilai normalisasi dari yang didapatkan dari nilai masing-masing kriteria penilaian level kompetensi pengajar dibagi dengan nilai maksimal dari masing-masing kriteria. Perhitungan untuk mencari nilai normalisasi dengan faktor kriteria benefit digunakan rumus:

$\mathbf{R}_{\mathrm{ii}}=\left(\mathbf{X}_{\mathrm{ij}} / \mathbf{m a x}\left\{\mathbf{X}_{\mathrm{ij}}\right\}\right)$
Tabel 4.3: Bobot Kriteria Metode SAW

\begin{tabular}{|c|c|c|c|c|c|c|c|c|}
\hline \multicolumn{10}{|c|}{ Bobot Kriteria } \\
\hline C1 & C2 & C3 & C4 & C5 & C6 & C7 & C8 & C9 \\
\hline 0,15 & 0,05 & 0,2 & 0,1 & 0,1 & 0,05 & 0,1 & 0,15 & 0,1 \\
\hline
\end{tabular}

Data pada Tabel 4.3 merupakan nilai pembobotan dari masing-masing kriteria untuk menentukan level kompetensi pengajar. Nilai pembobotan ini sudah ditentukan oleh manajemen NF COMPUTER.

\begin{tabular}{|c|c|c|c|c|c|c|c|c|c|c|}
\hline \multirow{2}{*}{$\mathbf{A}$} & \multicolumn{9}{|c|}{ Perkalian Matrik ( Normalisasi x Bobot) } & \multirow{2}{*}{$\mathbf{T}$} \\
\hline & C1 & $\mathrm{C2}$ & C3 & C4 & C5 & C6 & C7 & C8 & C9 & \\
\hline A1 & 0,13 & 0,04 & 0,16 & 0,08 & 0,01 & 0,03 & 0,07 & 0,02 & 0,02 & 0,55 \\
\hline $\mathrm{A} 2$ & 0,13 & 0,05 & 0,16 & 0,10 & 0,03 & 0,03 & 0,07 & 0,07 & 0,10 & 0,74 \\
\hline A3 & 0,12 & 0,05 & 0,20 & 0,09 & 0,05 & 0,03 & 0,07 & 0,05 & 0,01 & 0,66 \\
\hline A4 & 0,15 & 0,05 & 0,20 & 0,10 & 0,10 & 0,05 & 0,07 & 0,15 & 0,10 & 0,97 \\
\hline A5 & 0,13 & 0,05 & 0,18 & 0,10 & 0,05 & 0,04 & 0,07 & 0,10 & 0,10 & 0,82 \\
\hline A6 & 0,15 & 0,05 & 0,20 & 0,10 & 0,10 & 0,05 & 0,10 & 0,15 & 0,10 & 1,00 \\
\hline A7 & 0,11 & 0,03 & 0,14 & 0,06 & 0,01 & 0,03 & 0,07 & 0,02 & 0,10 & 0,57 \\
\hline A8 & 0,13 & 0,05 & 0,16 & 0,08 & 0,02 & 0,03 & 0,07 & 0,05 & 0,09 & 0,67 \\
\hline A9 & 0,13 & 0,05 & 0,20 & 0,08 & 0,03 & 0,03 & 0,07 & 0,15 & 0,10 & 0,84 \\
\hline A10 & 0,15 & 0,05 & 0,20 & 0,10 & 0,10 & 0,05 & 0,10 & 0,15 & 0,10 & 1,00 \\
\hline
\end{tabular}

Data pada Tabel 4.4 merupakan perkalian matrik antara nilai normalisasi yang sudah didapatkan dengan bobot masing-masing kriteria. Hasil dari nilai rating kerja ternormalisasi (rij) membentuk matrik ternormalisasi (R) dengan rumus:

$$
R=\left[\begin{array}{cccc}
r 11 & r 12 & \ldots & r i j \\
\vdots & & & \vdots \\
r i 1 & r i 2 & \ldots & r i j
\end{array}\right]
$$

Preferensi $\left(\mathbf{V}_{\mathbf{i}}\right)$ yang diperoleh dari penjumlahan dari perkalian elemen baris matrik ternormalisasi $(\mathbf{R})$ dengan bobot preferensi $(\mathbf{W})$ yang bersesuai elemen kolom matrik $(\mathbf{W})$ dengan rumus :

$$
V_{i}=\sum_{j=1}^{n} w_{j} r_{i j}
$$

Setelah didapatkan nilai akhir dari preferensi, maka dilakukan pemeringkatan yang didapat dari nilai hasil akhir yang paling besar, lalu menurun ke bawah dari nilai akhir yang lebih kecil dari hasil di atasnya dengan data peringkat sebagai berikut: 
Tabel 4.5: Nilai Akhir Preferensi Metode SAW

\begin{tabular}{|c|c|c|c|c|c|c|c|c|c|c|}
\hline \multirow{2}{*}{ A } & \multicolumn{9}{|c|}{ Nilai Prefensi Untuk Setiap Alternative (Vi) } & \multirow{2}{*}{$\mathbf{T}$} \\
\hline & C1 & C2 & C3 & C4 & C5 & C6 & C7 & C8 & C9 & \\
\hline A6 & 0,15 & 0,05 & 0,20 & 0,10 & 0,10 & 0,05 & 0,10 & 0,15 & 0,10 & 1,00 \\
\hline $\mathrm{A} 10$ & 0,15 & 0,05 & 0,20 & 0,10 & 0,10 & 0,05 & 0,10 & 0,15 & 0,10 & 1,00 \\
\hline $\mathrm{A} 4$ & 0,15 & 0,05 & 0,20 & 0,10 & 0,10 & 0,05 & 0,07 & 0,15 & 0,10 & 0,97 \\
\hline $\mathrm{A} 9$ & 0,13 & 0,05 & 0,20 & 0,08 & 0,03 & 0,03 & 0,07 & 0,15 & 0,10 & 0,84 \\
\hline A5 & 0,13 & 0,05 & 0,18 & 0,10 & 0,05 & 0,04 & 0,07 & 0,10 & 0,10 & 0,82 \\
\hline A2 & 0,13 & 0,05 & 0,16 & 0,10 & 0,03 & 0,03 & 0,07 & 0,07 & 0,10 & 0,74 \\
\hline A8 & 0,13 & 0,05 & 0,16 & 0,08 & 0,02 & 0,03 & 0,07 & 0,05 & 0,09 & 0,67 \\
\hline $\mathrm{A} 3$ & 0,12 & 0,05 & 0,20 & 0,09 & 0,05 & 0,03 & 0,07 & 0,05 & 0,01 & 0,66 \\
\hline A7 & 0,11 & 0,03 & 0,14 & 0,06 & 0,01 & 0,03 & 0,07 & 0,02 & 0,10 & 0,57 \\
\hline $\mathrm{A} 1$ & 0,13 & 0,04 & 0,16 & 0,08 & 0,01 & 0,03 & 0,07 & 0,02 & 0,02 & 0,55 \\
\hline
\end{tabular}

Data pada Tabel 4.5 merupakan hasil pemeringkatan dari nilai akhir preferensi yang didapat dari masing-masing pengajar dengan urutan ranking sebagai berikut :

1. Alternatif A6 atas nama pengajar Henry Saptono dengan nilai 1,00 .

2. Alternatif A10 atas nama pengajar Sirojul Munir dengan nilai 1,00

3. Alternatif A4 atas nama pengajar Nasrul dengan nilai 0,97 .

4. Alternatif A5 atas nama pengajar Edo Riasyah dengan nilai 0,84 .

5. Alternatif A9 atas nama pengajar Hafidz Attamim dengan nilai 0,82 .

6. Alternatif A2 atas nama pengajar Sugandi dengan nilai 0,74 .

7. Alternatif A8 atas nama pengajar Achmad Ilham dengan nilai 0,67 .

8. Alternatif A3 atas nama pengajar Yuliadi dengan nilai 0,66 .

9. Alternatif A7 atas nama pengajar Daseh Hidayat dengan nilai 0,57 .

10. Alternatif A1 atas nama pengajar Laisa Nurin Mentari dengan nilai 0,55 .

\subsection{Analisis Uji TOPSIS}

Dengan data uji yang sama, untuk tahap selanjutnya penulis menganalisis uji metode TOPSIS. Setelah mendapatkan hasil ujinya, kemudian dibandingkan dengan hasil uji metode SAW. Hasil uji yang terbaik akan diterapkan pada sebuah sistem informasi.
Tabel 4.6 : Konversi Data Awal Metode TOPSIS

\begin{tabular}{|c|c|c|c|c|c|c|c|c|c|}
\hline $\mathbf{A}$ & $\mathbf{C 1}$ & $\mathbf{C 2}$ & $\mathbf{C 3}$ & $\mathbf{C 4}$ & $\mathbf{C 5}$ & $\mathbf{C 6}$ & $\mathbf{C 7}$ & $\mathbf{C 8}$ & $\mathbf{C 9}$ \\
\hline A1 & 0,75 & 0,7 & 0,80 & 0,75 & 0,1 & 0,5 & 0,5 & 0,15 & 0,2 \\
\hline A2 & 0,75 & 1 & 0,80 & 1 & 0,3 & 0,5 & 0,5 & 0,45 & 1 \\
\hline A3 & 0,7 & 1 & 1,00 & 0,85 & 0,5 & 0,5 & 0,5 & 0,3 & 0,1 \\
\hline A4 & 0,85 & 1 & 1,00 & 1 & 1 & 0,9 & 0,5 & 1 & 1 \\
\hline A5 & 0,75 & 1 & 0,90 & 1 & 0,5 & 0,7 & 0,5 & 0,65 & 1 \\
\hline A6 & 0,85 & 1 & 1,00 & 1 & 1 & 1 & 0,7 & 1 & 1 \\
\hline A7 & 0,65 & 0,6 & 0,70 & 0,59 & 0,1 & 0,5 & 0,5 & 0,15 & 1 \\
\hline A8 & 0,75 & 1 & 0,80 & 0,75 & 0,2 & 0,5 & 0,5 & 0,3 & 0,9 \\
\hline A9 & 0,75 & 1 & 1,00 & 0,75 & 0,3 & 0,6 & 0,5 & 1 & 1 \\
\hline A10 & 0,85 & 1 & 1,00 & 1 & 1 & 1 & 0,7 & 1 & 1 \\
\hline
\end{tabular}

Data pada Tabel 4.6 merupakan konversi data awal dibagi 100 dari masing-masing alternatif yang selanjutnya akan dikalikan dengan perkalian matrik ternormalisasi.

Tabel 4.7: Perkalian Matrik Ternormalisasi Metode TOPSIS

\begin{tabular}{|l|r|}
\hline \multicolumn{1}{|c|}{ Variabel } & \multicolumn{1}{|c|}{ Hasil } \\
\hline $\mathrm{X} 1$ & 2,43 \\
\hline $\mathrm{X} 2$ & 2,97 \\
\hline $\mathrm{X} 3$ & 2,87 \\
\hline $\mathrm{X} 4$ & 2,79 \\
\hline $\mathrm{X} 5$ & 1,93 \\
\hline $\mathrm{X} 6$ & 2,22 \\
\hline $\mathrm{X} 7$ & 1,73 \\
\hline $\mathrm{X} 8$ & 2,20 \\
\hline $\mathrm{X} 9$ & 2,80 \\
\hline
\end{tabular}

Data pada Tabel 4.7 merupakan hasil perkalian matrik ternormalisasi yang didapat dari akar dari hasil pangkat nilai pada setiap kriteria. Dari hasil perkalian matrik inilah kemudian akan diolah datanya menjadi normalisasi $\mathrm{R}$.

Tabel 4.8 : Hasil Normalisasi Metode TOPSIS

\begin{tabular}{|c|c|c|c|c|c|c|c|c|c|}
\hline $\mathbf{A}$ & $\mathbf{C 1}$ & $\mathbf{C 2}$ & $\mathbf{C 3}$ & $\mathbf{C 4}$ & $\mathbf{C 5}$ & $\mathbf{C 6}$ & $\mathbf{C 7}$ & $\mathbf{C 8}$ & $\mathbf{C 9}$ \\
\hline $\mathbf{N}$ & $\mathbf{R 1}$ & $\mathbf{R 2}$ & $\mathbf{R 3}$ & $\mathbf{R 4}$ & $\mathbf{R 5}$ & $\mathbf{R 6}$ & $\mathbf{R 7}$ & $\mathbf{R 8}$ & $\mathbf{R 9}$ \\
\hline A1 & 0,31 & 0,24 & 0,28 & 0,27 & 0,05 & 0,23 & 0,29 & 0,07 & 0,07 \\
\hline A2 & 0,31 & 0,34 & 0,28 & 0,36 & 0,16 & 0,23 & 0,29 & 0,20 & 0,36 \\
\hline A3 & 0,29 & 0,34 & 0,35 & 0,31 & 0,26 & 0,23 & 0,29 & 0,14 & 0,04 \\
\hline A4 & 0,35 & 0,34 & 0,35 & 0,36 & 0,52 & 0,41 & 0,29 & 0,45 & 0,36 \\
\hline
\end{tabular}




\begin{tabular}{|l|l|l|l|l|l|l|l|l|l|} 
A5 & 0,31 & 0,34 & 0,31 & 0,36 & 0,26 & 0,32 & 0,29 & 0,30 & 0,36 \\
\hline A6 & 0,35 & 0,34 & 0,35 & 0,36 & 0,52 & 0,45 & 0,41 & 0,45 & 0,36 \\
\hline A7 & 0,27 & 0,20 & 0,24 & 0,21 & 0,05 & 0,23 & 0,29 & 0,07 & 0,36 \\
\hline A8 & 0,31 & 0,34 & 0,28 & 0,27 & 0,10 & 0,23 & 0,29 & 0,14 & 0,32 \\
\hline A9 & 0,31 & 0,34 & 0,35 & 0,27 & 0,16 & 0,27 & 0,29 & 0,45 & 0,36 \\
\hline A10 & 0,35 & 0,34 & 0,35 & 0,36 & 0,52 & 0,45 & 0,41 & 0,45 & 0,36 \\
\hline
\end{tabular}

Data pada Tabel 4.8 merupakan hasil normalisasi yang didapat dari data nilai dibagi dengan matriks ternormalisasi dari semua kriteria-kriteria dan alternatif-alternatif yang sudah ditentukan sebelumnya. Hal ini merupakan penerapan rumus awal metode TOPSIS:

$$
r_{i j}-\frac{x_{i, j}}{\sqrt{\sum_{i}^{m} x_{i j}^{2}}}
$$

Rumus di atas merupakan cara metode TOPSIS untuk menentukan rating kinerja setiap alternatif pada setiap kriteria yang ternormalisasi.

Tabel 4.9: Hasil Normalisasi Terbobot TOPSIS

\begin{tabular}{|c|c|c|c|c|c|c|c|c|c|}
\hline A & C1 & C2 & C3 & C4 & C5 & C6 & C7 & C8 & C9 \\
\hline B & Y1 & Y2 & Y3 & Y4 & Y5 & Y6 & Y7 & Y8 & Y9 \\
\hline A1 & 0,05 & 0,01 & 0,06 & 0,03 & 0,01 & 0,01 & 0,03 & 0,01 & 0,01 \\
\hline A2 & 0,05 & 0,02 & 0,06 & 0,04 & 0,02 & 0,01 & 0,03 & 0,03 & 0,04 \\
\hline A3 & 0,04 & 0,02 & 0,07 & 0,03 & 0,03 & 0,01 & 0,03 & 0,02 & 0,00 \\
\hline A4 & 0,05 & 0,02 & 0,07 & 0,04 & 0,05 & 0,02 & 0,03 & 0,07 & 0,04 \\
\hline A5 & 0,05 & 0,02 & 0,06 & 0,04 & 0,03 & 0,02 & 0,03 & 0,04 & 0,04 \\
\hline A6 & 0,05 & 0,02 & 0,07 & 0,04 & 0,05 & 0,02 & 0,04 & 0,07 & 0,04 \\
\hline A7 & 0,04 & 0,01 & 0,05 & 0,02 & 0,01 & 0,01 & 0,03 & 0,01 & 0,04 \\
\hline A8 & 0,05 & 0,02 & 0,06 & 0,03 & 0,01 & 0,01 & 0,03 & 0,02 & 0,03 \\
\hline A9 & 0,05 & 0,02 & 0,07 & 0,03 & 0,02 & 0,01 & 0,03 & 0,07 & 0,04 \\
\hline A10 & 0,05 & 0,02 & 0,07 & 0,04 & 0,05 & 0,02 & 0,04 & 0,07 & 0,04 \\
\hline
\end{tabular}

Data pada tabel 4.9 merupakan normalisasi terbobot yang hasilnya didapat dari data normalisasi dikali dengan bobot kriteria yang ada dengan rumus: $\mathbf{Y}_{\mathrm{ij}}=\mathbf{W}_{\mathbf{i}} \mathbf{r}_{\mathbf{i j}}$

Kemudian dari hasil di atas ditentukanlah matriks solusi ideal positif dan negatif, dengan data sebagai berikut:
Tabel 4.10 : Solusi Ideal Positif dan Negatif Metode TOPSIS

\begin{tabular}{|c|c|c|c|}
\hline Positif & A+ & Negatif & A- \\
\hline Y1+ & 0,05 & Y1- & 0,04 \\
\hline Y2+ & 0,02 & Y2- & 0,01 \\
\hline Y3+ & 0,07 & Y3- & 0,05 \\
\hline Y4+ & 0,04 & Y4- & 0,02 \\
\hline Y5+ & 0,05 & Y5- & 0,01 \\
\hline Y6+ & 0,02 & Y6- & 0,01 \\
\hline Y7+ & 0,04 & Y7- & 0,03 \\
\hline Y8+ & 0,07 & Y8- & 0,01 \\
\hline Y9+ & 0,04 & Y9- & 0,00 \\
\hline
\end{tabular}

Data pada Tabel 4.10 merupakan hasil perhitungan matriks solusi ideal positif dan negatif yang didapat dari kriteria berikut ini:

1. A+ = nilai maksimal dari hasil nilai kriteria terbobot.

2. A- $^{-}=$nilai minimal dari hasil nilai kriteria terbobot.

Tabel 4.11 : Jarak Alternatif Metode TOPSIS

\begin{tabular}{|c|c|c|c|}
\hline Jarak Alternatif & Positif(+) & Negatif(-) & D+ + D- \\
\hline A1 & 0,08 & 0,01 & 0,10 \\
\hline A2 & 0,06 & 0,04 & 0,10 \\
\hline A3 & 0,07 & 0,03 & 0,10 \\
\hline A4 & 0,01 & 0,09 & 0,10 \\
\hline A5 & 0,04 & 0,06 & 0,09 \\
\hline A6 & 0,00 & 0,09 & 0,09 \\
\hline A7 & 0,08 & 0,03 & 0,11 \\
\hline A8 & 0,07 & 0,03 & 0,10 \\
\hline A9 & 0,04 & 0,07 & 0,11 \\
\hline A10 & 0,00 & 0,09 & 0,09 \\
\hline
\end{tabular}

Data pada Tabel 4.11 merupakan jarak antara alternatif dengan matriks solusi ideal positif dan matriks solusi ideal negatif yang rumus sebagai berikut:

1. Positif $=$ Akar dari hasil $(A+$ dikurangi data terbobot) pangkat 2 yang merupakan penerapan dari rumus:

$D_{i}^{+}=\sqrt{\sum_{j=1}^{n}\left(y_{i}^{+}-y_{i j}\right)^{2}}$ 
2. Negatif $=$ Akar dari hasil (A- dikurangi data terbobot) pangkat 2 yang merupakan penerapan dari rumus:

$$
D_{i}^{-}=\sqrt{\sum_{j=1}^{m}\left(y_{i j}-y_{i}^{-}\right)^{2}} ;
$$

Tabel 4.12 : Hasil Akhir Metode TOPSIS

\begin{tabular}{|c|l|c|c|}
\hline Ranking & \multicolumn{1}{|c|}{ Nama Pengajar } & Alternatif & V \\
\hline 1 & Henry Saptono & A6 & 0,99 \\
\hline 2 & Sirojul Munir & A10 & 0,99 \\
\hline 3 & Nasrul & A4 & 0,88 \\
\hline 4 & Edo Riansyah & A9 & 0,64 \\
\hline 5 & Hafidz At-Tamim & A5 & 0,59 \\
\hline 6 & Sugandi & A2 & 0,43 \\
\hline 7 & Yuliadi & A3 & 0,33 \\
\hline 8 & Achmad Ilham & A8 & 0,33 \\
\hline 9 & Daseh Hidayat & A7 & 0,28 \\
\hline 10 & Laisa Nurin Mentari & A1 & 0,12 \\
\hline
\end{tabular}

Data pada Tabel 4.12 merupakan hasil akhir dan ranking dari setiap kriteria yang merupakan penerapan rumus berikut:

$$
\text { Vi = D- / (D+ + D-) }
$$

Hasil akhir dari setiap kriteria menyimpulan rangking level kompetensi pengajar yang paling tinggi dan berturut-turut ke bawahnya adalah pengajar atas nama Henry Saptono, Sirojul Munir, Nasrul dan seterusnya.

\subsection{Perbandingan Uji Analisis Metode SAW dan TOPSIS}

Berikut ini adalah perbandingan hasil uji analisis metode SAW dan TOPSIS yang telah penulis uji sebelumnya yang disajikan pada Tabel 4.13 :

Tabel 4.13 : Perbandingan Metode SAW dan TOPSIS

\begin{tabular}{|c|c|c|c|}
\hline \multirow[b]{2}{*}{ Ranking } & SAW & TOPSIS & \multirow{2}{*}{$\begin{array}{c}\text { Prosentase } \\
\text { Akurasi }\end{array}$} \\
\hline & $\begin{array}{c}\text { Nama } \\
\text { Pengajar }\end{array}$ & $\begin{array}{c}\text { Nama } \\
\text { Pengajar }\end{array}$ & \\
\hline 5 & Hafidz & $\begin{array}{l}\text { Edo } \\
\text { Riansyah }\end{array}$ & \\
\hline 6 & Sugandi & Sugandi & \multirow{5}{*}{60} \\
\hline 7 & Ilham & Yuliadi & \\
\hline 8 & Yuliadi & Ilham & \\
\hline 9 & $\begin{array}{l}\text { Daseh } \\
\text { Hidayat }\end{array}$ & $\begin{array}{l}\text { Daseh } \\
\text { Hidayat }\end{array}$ & \\
\hline 10 & Laisa & Laisa & \\
\hline
\end{tabular}

\begin{tabular}{|c|l|l|c|}
\hline \multirow{2}{*}{ Ranking } & \multicolumn{1}{|c|}{ SAW } & \multicolumn{1}{|c|}{ TOPSIS } & \multirow{2}{*}{$\begin{array}{c}\text { Prosentase } \\
\text { Nkurasi }\end{array}$} \\
\cline { 2 - 3 } & $\begin{array}{c}\text { Nama } \\
\text { Pengajar }\end{array}$ & $\begin{array}{c}\text { Nama } \\
\text { Pengajar }\end{array}$ & \\
\hline 1 & Henry & Henry & \multirow{2}{*}{100} \\
\hline 2 & $\begin{array}{l}\text { Sirojul } \\
\text { Munir }\end{array}$ & $\begin{array}{l}\text { Sirojul } \\
\text { Munir }\end{array}$ & \\
\hline 3 & Nasrul & Nasrul & \\
\hline 4 & $\begin{array}{l}\text { Edo } \\
\text { Riansyah }\end{array}$ & Hafidz & \\
\hline
\end{tabular}

Tabel 4.13 menunjukan perbandingan antara metode Simple Additive Weighting (SAW) dan metode Technique For Order By Similarity To Ideal Solution (TOPSIS). Perbandingan peringkat lima teratas mendapatkan hasil 100\% kesamaan keduanya. Sedangkan untuk peringkat lima ke bawah, hasil perbandingan menunjukan hasil $60 \%$ kesamaan. Dengan demikian hasil analisis metode SAW dan TOPSIS memiliki hasil yang tidak jauh berbeda.

\subsection{Pendapat Pakar}

Penulis dalam hal ini meminta pendapat para pakar dari pejabat NF COMPUTER, yang expert untuk menilai level kompetensi pengajar. Untuk mempermudah perhitungan, pengajar yang mendapatkan peringkat pertama mendapat nilai 10, peringkat kedua mendapat nilai 9, peringkat ketiga dan seterusnya mendapatkan nilai minus satu dari nilai pengajar peringkat di atasnya.

Dari penilaian para pakar, dapat dirangkum hasil penilaian para pakar dengan menjumlah poin masingmasing pengajar dari seluruh penilaian ketiga pakar dengan data sebagai berikut:

Tabel 4.14 : Kesimpulan Penilaian Para Pakar

\begin{tabular}{|c|l|l|c|}
\hline Ranking & Alternatif & \multicolumn{1}{|c|}{ Pengajar } & Total \\
\hline 1 & A10 & Sirojul Munir & 29 \\
\hline 2 & A6 & Henry Saptono & 28 \\
\hline 3 & A4 & Nasrul & 24 \\
\hline 4 & A9 & Edo Riansyah & 20 \\
\hline 5 & A5 & Hafidz At-Tamim & 18 \\
\hline 6 & A2 & Sugandi & 16 \\
\hline 7 & A8 & Achmad Ilham & 11 \\
\hline 8 & A3 & Yuliadi & 10 \\
\hline 9 & A7 & Daseh Hidayat & 6 \\
\hline 10 & A1 & Laisa Nurin Mentari & 3 \\
\hline
\end{tabular}


Pada Tabel 4.14 menunjukkan hasil kesimpulan penilaian ketiga pakar, peringkat pertama Bapak Sirojul Munir, peringkat kedua Bapak Henry Saptono dan seterusnya. Dari hasil kesimpulan ini kemudian dibandingan dengan hasil perhitungan dengan metode Simple Additive Weighting (SAW) dan metode Technique For Order By Similarity To Ideal Solution (TOPSIS).

\subsection{Perbandingan Hasil Uji Metode TOPSIS dan Para Pakar}

Dari hasil uji analisis metode Technique For Order By Similarity To Ideal Solution (TOPSIS) sebelumnya, penulis bandingkan dengan hasil penilaian para pakar dengan hasil perbandingan sebagai berikut:

Tabel 4.15 : Perbandingan Hasil Uji Metode TOPSIS

\begin{tabular}{|c|c|c|c|}
\hline \multirow{3}{*}{ Ranking } & \multicolumn{2}{|c|}{ dengan Pakar } & \multirow{3}{*}{$\begin{array}{c}\text { Prosentase } \\
\text { Akurasi }\end{array}$} \\
\hline & TOPSIS & Pakar & \\
\hline & $\begin{array}{c}\text { Nama } \\
\text { Pengajar }\end{array}$ & $\begin{array}{c}\text { Nama } \\
\text { Pengajar }\end{array}$ & \\
\hline 1 & Henry & $\begin{array}{l}\text { Sirojul } \\
\text { Munir }\end{array}$ & \multirow{5}{*}{80} \\
\hline 2 & $\begin{array}{l}\text { Sirojul } \\
\text { Munir }\end{array}$ & Henry & \\
\hline 3 & Nasrul & Nasrul & \\
\hline 4 & $\begin{array}{l}\text { Edo } \\
\text { Riansyah }\end{array}$ & $\begin{array}{l}\text { Edo } \\
\text { Riansyah }\end{array}$ & \\
\hline 5 & Hafidz & Hafidz & \\
\hline 6 & Sugandi & Sugandi & \multirow{5}{*}{60} \\
\hline 7 & Yuliadi & Ilham & \\
\hline 8 & Ilham & Yuliadi & \\
\hline 9 & $\begin{array}{l}\text { Daseh } \\
\text { Hidayat }\end{array}$ & $\begin{array}{l}\text { Daseh } \\
\text { Hidayat }\end{array}$ & \\
\hline 10 & Laisa & Laisa & \\
\hline
\end{tabular}

Tabel 4.15 menunjukkan hasil perbandingan antara hasil uji metode TOPSIS dengan hasil penilaian para pakar. Perbandingan peringkat lima teratas mendapatkan hasil $80 \%$ akurasi kesamaan peringkat. Sedangkan untuk peringkat lima ke bawah, hasil perbandingan menunjukan hasil $60 \%$ akurasi kesamaan peringkat.

\subsection{Perbandingan Hasil Uji Metode SAW dan Para Pakar}

Dari hasil uji analisis metode Simple Additive Weighting (SAW) sebelumnya, penulis bandingkan dengan hasil penilaian para pakar dengan hasil perbandingan sebagai berikut:
Tabel 4.16 : Perbandingan Hasil Uji Metode SAW dengan

\begin{tabular}{|c|c|c|c|}
\hline \multirow{3}{*}{ Ranking } & & akar & \multirow{3}{*}{$\begin{array}{c}\text { Prosentase } \\
\text { Akurasi }\end{array}$} \\
\hline & SAW & Pakar & \\
\hline & $\begin{array}{c}\text { Nama } \\
\text { Pengajar }\end{array}$ & $\begin{array}{c}\text { Nama } \\
\text { Pengajar }\end{array}$ & \\
\hline 1 & $\begin{array}{l}\text { Henry } \\
\text { Saptono }\end{array}$ & $\begin{array}{l}\text { Sirojul } \\
\text { Munir }\end{array}$ & \multirow{5}{*}{80} \\
\hline 2 & $\begin{array}{l}\text { Sirojul } \\
\text { Munir }\end{array}$ & $\begin{array}{l}\text { Henry } \\
\text { Saptono }\end{array}$ & \\
\hline 3 & Nasrul & Nasrul & \\
\hline 4 & $\begin{array}{l}\text { Edo } \\
\text { Riansyah }\end{array}$ & Hafidz & \\
\hline 5 & Hafidz & $\begin{array}{l}\text { Edo } \\
\text { Riansyah }\end{array}$ & \\
\hline 6 & Sugandi & Sugandi & \multirow{5}{*}{100} \\
\hline 7 & $\begin{array}{l}\text { Achmad } \\
\text { Ilham }\end{array}$ & $\begin{array}{l}\text { Achmad } \\
\text { Ilham }\end{array}$ & \\
\hline 8 & Yuliadi & Yuliadi & \\
\hline 9 & $\begin{array}{l}\text { Daseh } \\
\text { Hidayat }\end{array}$ & $\begin{array}{l}\text { Daseh } \\
\text { Hidayat }\end{array}$ & \\
\hline 10 & Laisa & Laisa & \\
\hline
\end{tabular}

Tabel 4.16 menunjukkan hasil perbandingan antara hasil uji metode SAW dengan hasil penilian para pakar. Perbandingan peringkat lima teratas mendapatkan hasil $80 \%$ akurasi kesamaan rangking. Sedangkan untuk peringkat lima ke bawah, hasil perbandingan menunjukan hasil $100 \%$ akurasi kesamaan peringkat.

\subsection{Kesimpulan}

Dari hasil perbandingan hasil uji metode SAW, TOPSIS dan penilaian para pakar, maka dapat disimpulkan sebagai berikut:

1. Perbandingan hasil uji metode TOPSIS dengan pendapat pakar:

a. Peringkat lima teratas $80 \%$ kesamaan hasil.

b. Peringkat lima terbawah $60 \%$ kesamaan hasil.

2. Perbandingan hasil uji metode SAW dengan pendapat pakar:

a. Peringkat lima teratas $80 \%$ kesamaan hasil.

b. Peringkat lima terbawah $100 \%$ kesamaan hasil.

Dengan hasil kesimpulan di atas, maka penulis dengan ini memilih metode Simple Additive Weighting (SAW) daripada metode Technique For Order By Similarity To Ideal Solution (TOPSIS) untuk menentukan level kompetensi pengajar NF COMPUTER, karena metode SAW mendapatkan hasil yang lebih baik daripada metode TOPSIS. 
Selanjutnya metode SAW ini akan diterapkan ke perancangan sistem Competency Mapping System pada NF COMPUTER.

\subsection{Perancangan Sistem}

Dalam perancangan sistem ini penulis menggunakan metode pengembangan software dengan metodologi Unified Process. Sifatnya yang iteratif dan bertahap membuat metode ini dipilih oleh penulis, karena melakukan perbaikan berulang-ulang sampai sesuai kebutuhan user.

\subsubsection{Use Case Diagram}

Gambar 4.1 menjelaskan tentang use case diagram pemetaan kompetensi pengajar yang berhasil dikumpulkan berdasarkan user requirement yang sudah dibuat sebelumnya.

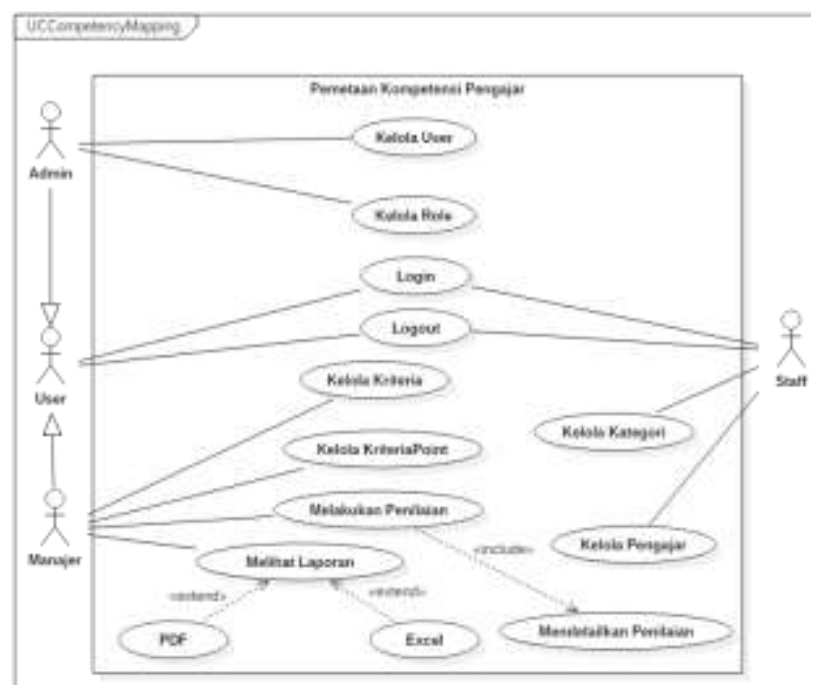

Gambar 4.1 : Use Case Diagram

Dari diagram use case pada Gambar 4.1 dapat dijelaskan bahwa untuk memasuki halaman aplikasi, user harus login terlebih dahulu dengan account user yang telah terdaftar di sistem. User admin dapat mengelola user dan hak akses user. User manajer dapat mengelola kriteria penilaian, kriteria point, melakukan penilaian level pengajar dan melihat laporan dalam bentuk PDF dan Ms. Excel. Untuk user staff bertugas untuk mengelola master data yaitu data kategori pengajar dan data pengajar.

\subsubsection{Class Diagram}

Class diagram juga merupakan bagian dari domain model, hanya saja pada class diagram ini dilengkapi dengan operasi-operasi standar yang akan dilakukan pada tiap objek. Berikut ini adalah bentuk dari class diagram competency mapping system:

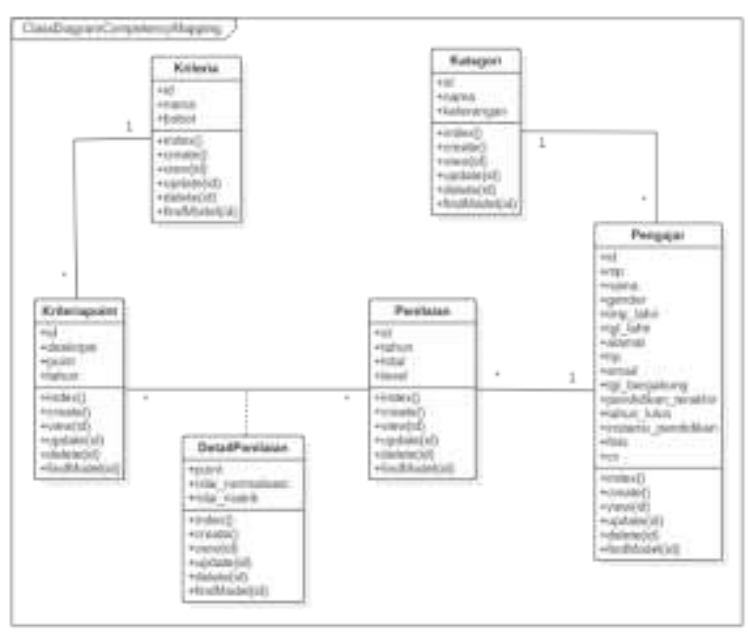

Gambar 4.2 : Class Diagram

Pada Gambar 4.2 dapat dijelaskan class diagram sistem yang akan dibangun. Masing-masing objek memiliki operasi-operasi umum untuk mengelola data di antaranya adalah:

1. Operasi create() berfungsi untuk menginput data.

2. Operasi view(id) berfungsi untuk menampilkan satu baris data.

3. Operasi update(id) berfungsi untuk mengubah satu baris data.

4. Operasi delete(id) berfungsi untuk menghapus data.

\subsubsection{Activity Diagram}

Diagram ini menggambarkan tentang aktifitas yang terjadi pada sistem. Dari pertama sampai akhir, diagram ini menunjukkan langkah - langkah dalam proses kerja sistem yang dibuat. Fungsi dari activity diagram diantaranya menggambarkan proses bisnis dan urutan aktivitas dalam sebuah proses, memperlihatkan urutan aktifitas proses pada sistem. Activity diagram dibuat berdasarkan sebuah atau beberapa use case diagram. Berikut ini contoh activity diagram utama dari bisnis proses competency mapping system yaitu penilaian level kompetensi pengajar.

Gambar 4.3 merupakan activity diagram penilaian level kompetensi pengajar yang menggambarkan langkah-langkah proses kerja sistem untuk menilai level kompetensi seorang pengajar,mulai dari pengisian kriteria-kriteria point untuk menentukan level kompetensi pengajar, lalu memproses datanya dengan metode Simple Additive Weigthing hingga mendapatkan hasil level kompetensi pengajar. Untuk activity diagram lainnya, penulis lampiran pada lampiran kedua. 


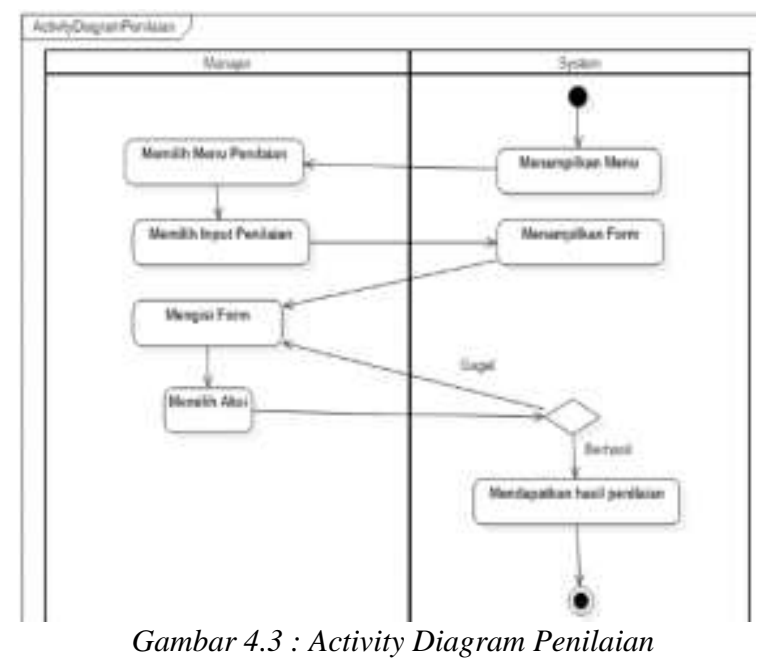

\subsection{Implementasi Sistem}

Pada tahap implementasi ini mulai memasuki fase utamanya adalah proses implementasi dan pengujian. Implementasi yang di maksud adalah dilakukannya proses pembuatan kode program untuk mewujudkan desain yang telah dibuat sebelumnya. Berikut ini implementasi antar muka dari aplikasi yang sudah dibuat :

\subsubsection{Halaman Home Aplikasi}

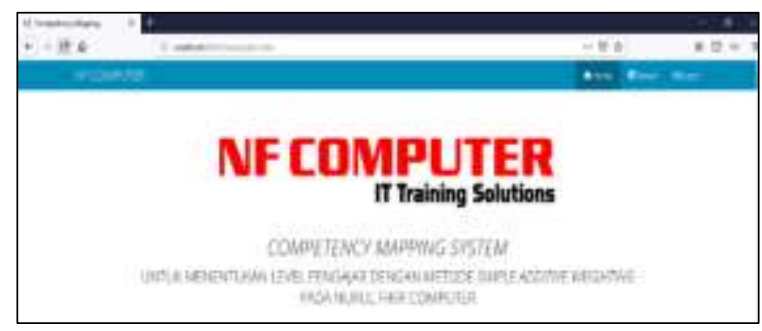

Gambar 4.4: User Interface Halaman Home

Gambar 4.4 merupakan halaman home aplikasi dengan adanya logo NF COMPUTER dan tema aplikasi. Ketika user belum login, menu utama hanya home, about dan login.

\subsubsection{Halaman Data Pengajar}

Gambar 4.5 merupakan halaman data detil pengajar. Di halaman ini user dapat melihat data detil pengajar. Pada halaman ini dilengkapi fitur unduh file curiculum vitae pengajar.

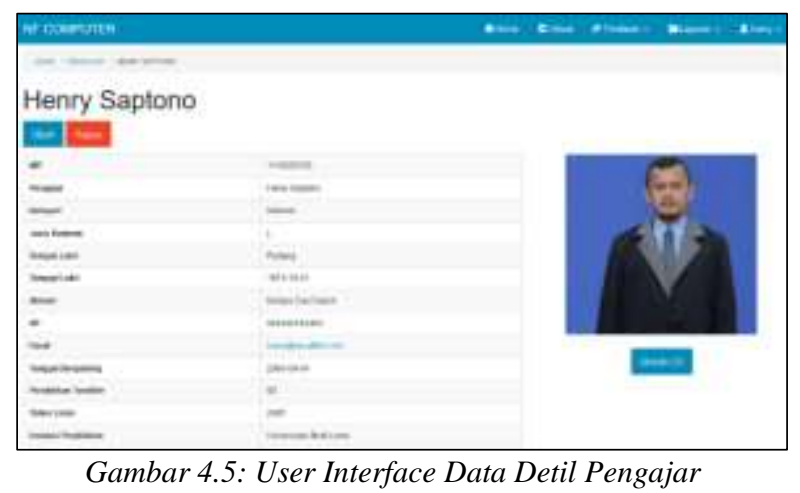

\subsubsection{Halaman Kelola Bobot Kriteria Penilaian}

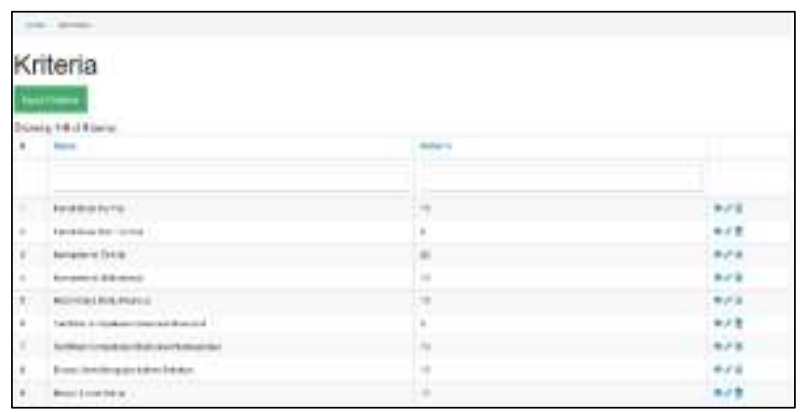

Gambar 4.6: User Interface Kelola Poin Kriteria Penilaian

Gambar 4.6 merupakan halaman kelola kriteria untuk menentukan leveling seorang pengajar. Di halaman ini ditentukan besarnya bobot dari masingmasing kriteria oleh user manajer.

\subsubsection{Halaman Kelola Poin Kriteria Penilaian}

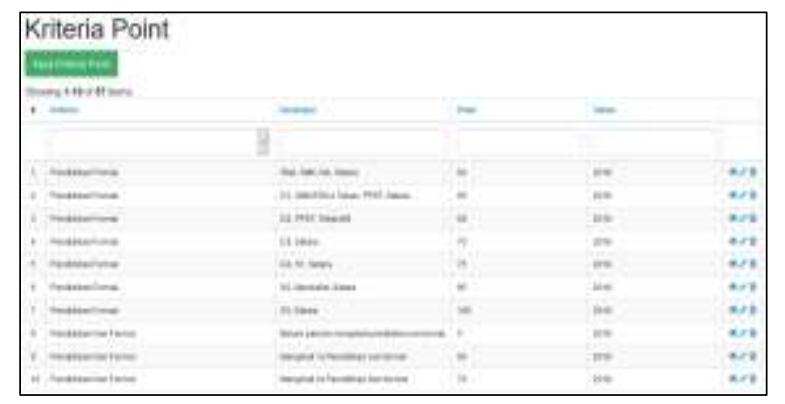

Gambar 4.7: User Interface Kelola Kriteria

Gambar 4.7 merupakan halaman kelola poin-poin dari masing-masing kriteria yang sudah ditentukan sebelumnya untuk menentukan leveling seorang pengajar. Di halaman ini ditentukan besarnya poinpoin dari masing-masing kriteria oleh user manajer. 


\subsubsection{Halaman Form Input Penilaian Pengajar}

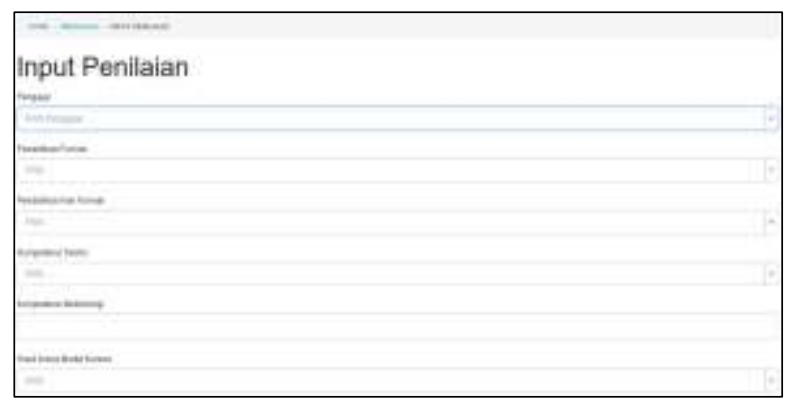

Gambar 4.8 : User Interface Input Penilaian

Gambar 4.8 merupakan halaman form input penilaian pengajar. Di halaman ini akan dinilai semua kriteria oleh user manajer.

\subsubsection{Halaman Hasil Penilaian Pengajar}

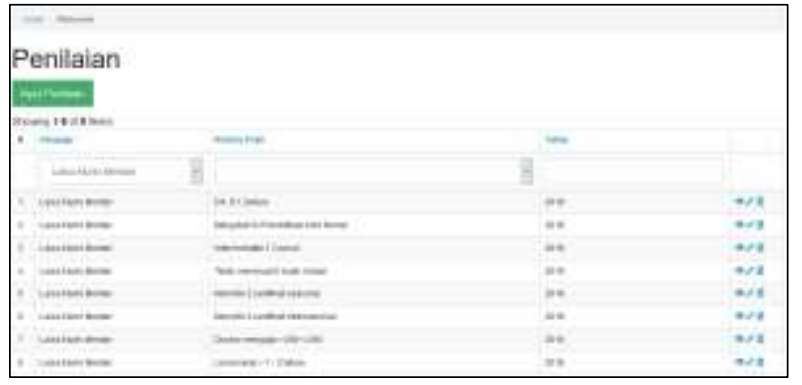

Gambar 4.9 : Hasil Input Penilaian

Gambar 4.9 merupakan halaman hasil input form penilaian pengajar dari semua kriteria-kriteria yang ditentukan sebelumnya. Di halaman ini akan terlihat poin-poin yang didapat oleh seorang pengajar.

\subsubsection{Hasil Akhir}

Pada Gambar 4.10 merupakan halaman hasil akhir dari semua perhitungan kriteria dan bobot yang telah ditentukan oleh manajemen NF COMPUTER untuk menentukan level kompetensi seorang pengajar dari hasil akhir perhitungan sistem hasil sama persis dengan perhitungan manual rumus metode Simple Additive Weighting. Dengan demikian perancangan Competency Mapping System dengan metode Simple Additive Weighting dapat diterapkan dengan baik dan dapat menentukan level kompetensi pengajar NF COMPUTER dengan tepat.

\subsection{Pengujian Sistem}

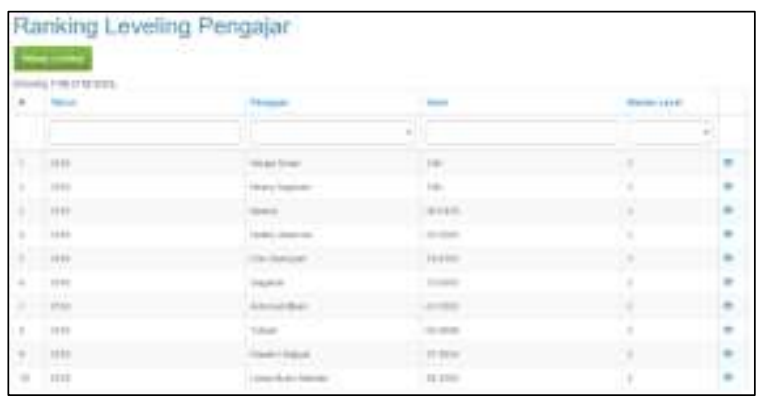

Gambar 4.10 : Hasil Akhir

Tahapan selanjutnya penulis, melakukan tahapan pengujian validasi aplikasi untuk memastikan perangkat lunak yang dibuat sesuai dengan kebutuhan yang diharapkan. Hal ini juga untuk menguji hipotesis pada penelitian ini. Berikut ini adalah keterangan dan penilaian kuisioner User Acceptance Test (UAT) yang diisi oleh lima orang responden yang merupakan pengguna aplikasi ini, dengan keterangan dan penilaian kuisioner sebagai berikut :

$\begin{array}{cl}\text { Jawaban } & \begin{array}{c}\text { Tabel } 4.17 \text { : Pilihan Jawaban } \\ \text { Keterangan }\end{array} \\ \text { A } & \text { Sangat Mudah/Bagus/Sesuai/Jelas } \\ \text { B } & \text { Mudah/Bagus/Sesuai/Jelas } \\ \text { C } & \text { Netral } \\ \text { D } & \text { Sulit/Tidak Bagus/Tidak Sesuai/Tidak } \\ & \text { Jelas } \\ \text { E } & \text { Sangat Sulit/Jelek/Tidak Sesuai/Tidak } \\ & \text { Jelas }\end{array}$

Tabel 4.17 merupakan pilihan jawaban kuisioner UAT, mulai pilihan jawaban A yang berarti sangat mudah/bagus/sesuai/jelas dan seterusnya, yang nantinya disesuaikan dengan pertanyaan yang diajukan kepada responden.

Tabel 4.18:Bobot Nilai Jawaban

\begin{tabular}{|c|c|c|}
\hline Bobot & Jawaban & Keterangan \\
\hline 5 & A & Sangat Mudah/Bagus/Sesuai/Jelas \\
\hline 4 & B & Mudah/Bagus/Sesuai/Jelas \\
\hline 3 & $\mathrm{C}$ & Netral \\
\hline 2 & $\mathrm{D}$ & $\begin{array}{l}\text { Sulit/Tidak Bagus/Tidak } \\
\text { Sesuai/Tidak Jelas }\end{array}$ \\
\hline 1 & $\mathrm{E}$ & $\begin{array}{l}\text { Sangat Sulit/Jelek/Tidak } \\
\text { Sesuai/Tidak Jelas }\end{array}$ \\
\hline
\end{tabular}

Tabel 4.18 merupakan nilai bobot dari pilihan jawaban kuisioner UAT, mulai pilihan jawaban A yang bernilai bobot 5, jawaban B yang bernilai bobot 4 dan seterusnya sesuai Tabel $4.18 \mathrm{di}$ atas. 
Tabel 4.19: Nilai Presentase

$\begin{array}{rc}\text { Rentang Nilai } & \text { Keterangan } \\ 91-100 & \text { Sangat Baik } \\ 81-90 & \text { Baik } \\ 71-80 & \text { Cukup Baik } \\ 61-70 & \text { Sedang } \\ 51-60 & \text { Kurang }\end{array}$

Tabel 4.19 merupakan nilai presentase dari hasil akhir penilaian kuisioner UAT dari responden. Dari nilai inilah akan diketahui hasil pengujian akhir aplikasi apakah aplikasi ini baik atau tidak tergantung nilai akhir yang didapat.

Dari hasil kesimpulan pengujian UAT yang telah dilakukan, hasil rata-rata bobot yang didapat adalah $81 \%$. Maka dapat disimpulkan bahwa hasil pengujian sistem dengan UAT ini hasilnya adalah baik.Secara fungsional sistem ini dapat diterima oleh pengguna dan dapat memberikan solusi bagi NF COMPUTER untuk menentukan level pengajar dengan tepat.

\section{Kesimpulan dan Saran 5.1 Kesimpulan}

Pada penelitian yang telah dilakukan, dapat disimpulkan bahwa kinerja metode Simple Additive Weighting (SAW) adalah baik untuk menentukan level kompetensi pengajar dengan tepat dan dapat diaplikasikan ke dalam sebuah sistem informasi pada NF COMPUTER. Hal ini telah dibuktikan pada perbandingan dua metode yang termasuk ke dalam kategori Multiple Attribute Decision Making (MADM) yaitu perbandingan metode Simple Additive Weighting (SAW) dan metode Tecnique for Order Preference by Similarity to Ideal Solution (TOPSIS) yang dibandingkan dengan pendapat para pakar. Hasil perbandingan tersebut menghasilkan metode SAW lebih baik daripada metode TOPSIS, karena metode TOPSIS menghasilkan $80 \%$ sama pada lima peringkat teratas dari pendapat sistem pakar dan hanya $60 \%$ sama pada lima peringkat terbawah dari pendapat sistem pakar. Sedang hasil perbandingan metode SAW $80 \%$ sama pada lima peringkat teratas dari pendapat sistem pakar dan $100 \%$ sama pada lima peringkat terbawah dari pendapat sistem pakar. Setelah itu metode terbaik yaitu metode SAW dirancang dan dibangun pada sebuah sistem informasi yang kemudian diuji validitas fungsionalitas sistemnya dengan menggunakan User Acceptance Test (UAT) dengan hasil uji $81 \%$, dengan demikian kinerja sistem tersebut adalah baik.

\subsection{Saran}

Penulis dalam menentukan level kompetensi pengajar melakukan pendekatkan sistem pendukung keputusan dengan metode Multiple Attribute Decision Making (MADM) merupakan metode pengambilan keputusan dengan banyaknya alternatif berdasarkan beberapa kriteria yang telah ditentukan. Dalam penelitian ini, penulis hanya membandingkan dua metode yang termasuk dalam kategori Multiple Attribute Decision Making (MADM), yaitu Simple Additive Weighting (SAW) dan metode Tecnique for Order Preference by Similarity to Ideal Solution (TOPSIS). Oleh karena itu untuk penelitian selanjutnya, penulis menyarankan membandingkan dengan kategori metode MADM lainnya seperti Weighted Product (WP), Analytic Hierarchy Process (AHP) dan ELECTRE untuk mendapatkan hasil yang lebih tepat.

\section{Daftar Pustaka}

[1] Poerwadarminta, Kamus Besar Bahasa Indonesia. Bandung: Hasta, 1999.

[2] S. Sagala, Kemampuan Professional Guru dan Tenaga Kependidikan. Bandung: Alfabeta, 2009.

[3] Uno, Model Pembelajaran Menciptakan Proses Belajar Mengajar yang Kreatif dan Efektif. Jakarta: Bumi Aksara, 2007.

[4] Palan, Teknis Mengimplementasikan Manajemen SDM Berbasis Kompetensi untuk Meningkatkan Daya Saing Organisasi. Jakarta: PPM, 2007.

[5] Mulyasa, Implementasi Kurikulum 2004 Panduan Pembelajaran KBK. Remaja Rosda Karya, 2004.

[6] Z. Asril, Microteaching. Jakarta: Rajawali Pers, 2010.

[7] Trianto, Yuridis Hak Serta Kewajiban Pendidik Menurut Uu Guru Dan Dosen. Jakarta: Prestasi Pustaka, 2006.

[8] W. Kusumadewi, Hartati, Harjoko, Fuzzy Multi Attribute Decision Making (Fuzzy MADM). Yogyakarta: Graha Ilmu, 2006.

[9] P. S. Hasugian, H. D. Hutahaean, and H. T. Sihotang, "Sistem Pendukung Keputusan Penentuan Guru Wali Kelas Pada SMP Negeri 19 Medan Dengan Menggunakan Metode Simple Additive Weighting" J. Inform. Pelita Nusant., vol. 2, no. 1, pp. 32-39, 2017.

[10] Moleng, Metode Penelitian Kualitatif. Bandung: Remaja Rosdakarya, 2002. 